\title{
ELECTRON MICROSCOPE EVALUATION OF RABBIT EGGS EXPOSED TO SPERMATOZOA TREATED WITH CAPACITATING AGENTS
}

\author{
P. V. DANDEKAR AND M. GORDON \\ Department of Obstetrics and Gynecology, Yale University School of Medicine, \\ New Haven, Connecticut 06510, U.S.A.
}

(Received 23rd December 1974)

Sperm capacitation (Austin, 1951; Chang, 1951) normally occurs in the female genital tract. The mechanism of capacitation is unknown. Agents considered to induce capacitation may be tested in vitro and the subsequent criteria for fertilization have been (1) the production of cleaved ova and, (2) the viability of embryos transferred to recipient females.

In laboratory rodents, spermatozoa have been capacitated with enzymes, salt solutions or body fluids, but rabbit spermatozoa have not been easily capacitated in vitro. The evidence for amylase activity in rabbit uterine fluid (Kirton \& Hafs, 1965), $\beta$-glucuronidase in rat uteri (Hayashi, 1964) and data indicating that $\alpha$ - and $\beta$-amylase destroy capacitation factor (Dukelow, Chernoff \& Williams, 1967) led to experiments with these enzymes on rabbit spermatozoa. Incubation with $\beta$-amylase and uterine fluid shortened the time necessary for capacitation in vivo (Kirton \& Hafs, 1965). In similar experiments, Johnson \& Hunter (1972) concluded that $\beta$-amylase and $\beta$-glucuronidase initiated capacitation because they remove seminal antigens from the sperm surface. They attributed the action of blood sera on spermatozoa (Barros \& Garavagno, 1970) to the presence of $\beta$-amylase and $\beta$-glucuronidase. Cleavage of rabbit eggs in vitro, however, was obtained after spermatozoa were exposed to postovulatory uterine fluid (Brackett \& co-authors, 1972), McCoy's modified medium (Iwaki, 1971) and human follicular fluid (HFF) (Rosado, Hick, Reyes \& Blanco, 1974). After sperm penetration, the fertilized ovum is devoid of cortical granules. The activated egg, although appearing to undergo normal cleavage, retains the granules (Longo, 1974). Cleaved cells resulting from incubation with 'capacitated' spermatozoa have not been previously assessed for cortical granules.

In this report we investigated the effect of bovine follicular fluid (BFF), HFF, uterine fluid, McCoy's modified medium, $\beta$-amylase, trypsin and chymotrypsin on rabbit spermatozoa in vitro. The treated spermatozoa were then exposed to eggs in vitro (Fraser, Dandekar \& Vaidya, 1971). Gleaved cells were examined by electron microscopy for the presence of cortical granules. Trypsin and chymotrypsin were tested because of the observation that spermatozoa capacitated in vivo shed portions of the surface coat (Gordon, Dandekar \& 
Bartoszewicz, 1974). In other cells, trypsin has been shown to promote shedding of the glycoprotein coat (Kapeller, Gal-oz, Grover \& Doljanski, 1973).

Ejaculates were collected with an artificial vagina and checked for motility and sperm count. They were then washed in fertilization medium (Fraser et al., 1971 ) and the count was adjusted to $1 \times 10^{6} \mathrm{cells} / \mathrm{ml}$. The following incubations were carried out. (1) A solution of one of the following in fertilization medium was added to the sperm pellet; trypsin, $10 \mu \mathrm{g} / \mathrm{ml}, 50 \mu \mathrm{g} / \mathrm{ml}, 200 \mu \mathrm{g} / \mathrm{ml}$; chymotrypsin, $10 \mu \mathrm{g} / \mathrm{ml} ; \beta$-amylase, $1 \mathrm{mg} / \mathrm{ml}$. After incubation for $45 \mathrm{~min}$ at $37^{\circ} \mathrm{C}$ in a humid atmosphere with $5 \% \mathrm{CO}_{2} / 95 \%$ air, the samples were centrifuged, washed and resuspended in $4 \mathrm{ml}$ fertilization medium. (2) Preovulatory uterine fluid was collected from does whose uterine horns were ligated 4 to 5 days earlier, and postovulatory fluid from a doe primed with gonadotrophins. Spermatozoa were added to $1 \mathrm{ml}$ fluid. After incubation for $1 \mathrm{hr}$, the volume was adjusted to $4 \mathrm{ml}$ with fertilization medium. (3) Aliquots $(0.3 \mathrm{ml})$ of washed spermatozoa in medium were added to $0.3 \mathrm{ml}$ of BFF or HFF after washing in Tyrode's solution containing $50 \mathrm{mg}$ penicillin ' $\mathrm{G}$ '/ $\mathrm{ml}$. After incubation for $1 \mathrm{hr}$ or for $12 \mathrm{hr}$, the volume was adjusted to $4 \mathrm{ml}$ with fertilization medium. (4) McCoy's modified medium ( $1 \mathrm{ml}$ ) was added to washed spermatozoa, incubated for $1 \mathrm{hr}$ and the volume was adjusted to $4 \mathrm{ml}$ with the same medium. (5) Control spermatozoa were incubated in fertilization medium or Tyrode's solution.

Treated spermatozoa as well as spermatozoa capacitated in vivo were mixed with eggs devoid of corona cells. Eggs not exposed to spermatozoa were incubated in fertilization medium and in each of the test media. After incubation for 4 to $5 \mathrm{hr}$, the eggs were transferred to culture medium and incubated at $37^{\circ} \mathrm{C}$ in air for $22 \mathrm{hr}$. Pronuclear, two-cell and four-cell stages were fixed in $2 \%$ osmium tetroxide, dehydrated and embedded in Spurr. Silver sections were stained with uranyl acetate and lead citrate.

There was no visible change in untreated ova or in ova incubated without spermatozoa in McCoy's medium, HFF, BFF or medium containing enzymes. They did not develop pronuclei or cleave. Similar results were obtained when ova were exposed to spermatozoa incubated in fertilization medium or in Tyrode's solution. Eggs that were placed with spermatozoa capacitated in vivo developed to the two- (Pl. 1, Fig. 1), four-and eight-cell stages. When examined by electron microscopy, they had no cortical granules (Pl. 1, Fig. 3b).

\section{EXPLANATION OF PLATE 1}

FIG. 1. A two-cell rabbit embryo, showing polar bodies in the perivitelline space (arrow). Eggs were exposed to spermatozoa capacitated in vivo. $\times 270$.

Fig. 2. A two-cell rabbit embryo developed after the ovum was incubated with treated spermatozoa. A polar body is visible in the perivitelline space (arrow). Many spermatozoa are adhering to the zona. $\times 310$.

Fig. 3. The cortical cytoplasm of a cleaved rabbit ovum developed after exposure to treated spermatozoa. One section of the cytoplasm (a) contains numerous cortical granules similar to those in an unfertilized egg. Another region of the ovum (b) is devoid of cortical granules and resembles a fertilized cell. (a) $\times 11,340$, (b) $\times 12,870$.

Fig. 4. Two cells produced after exposure of a rabbit ovum to treated spermatozoa. They are indistinguishable from normal embryos except for numerous cortical granules (arrow). $\times 3825$. 
PLATE 1
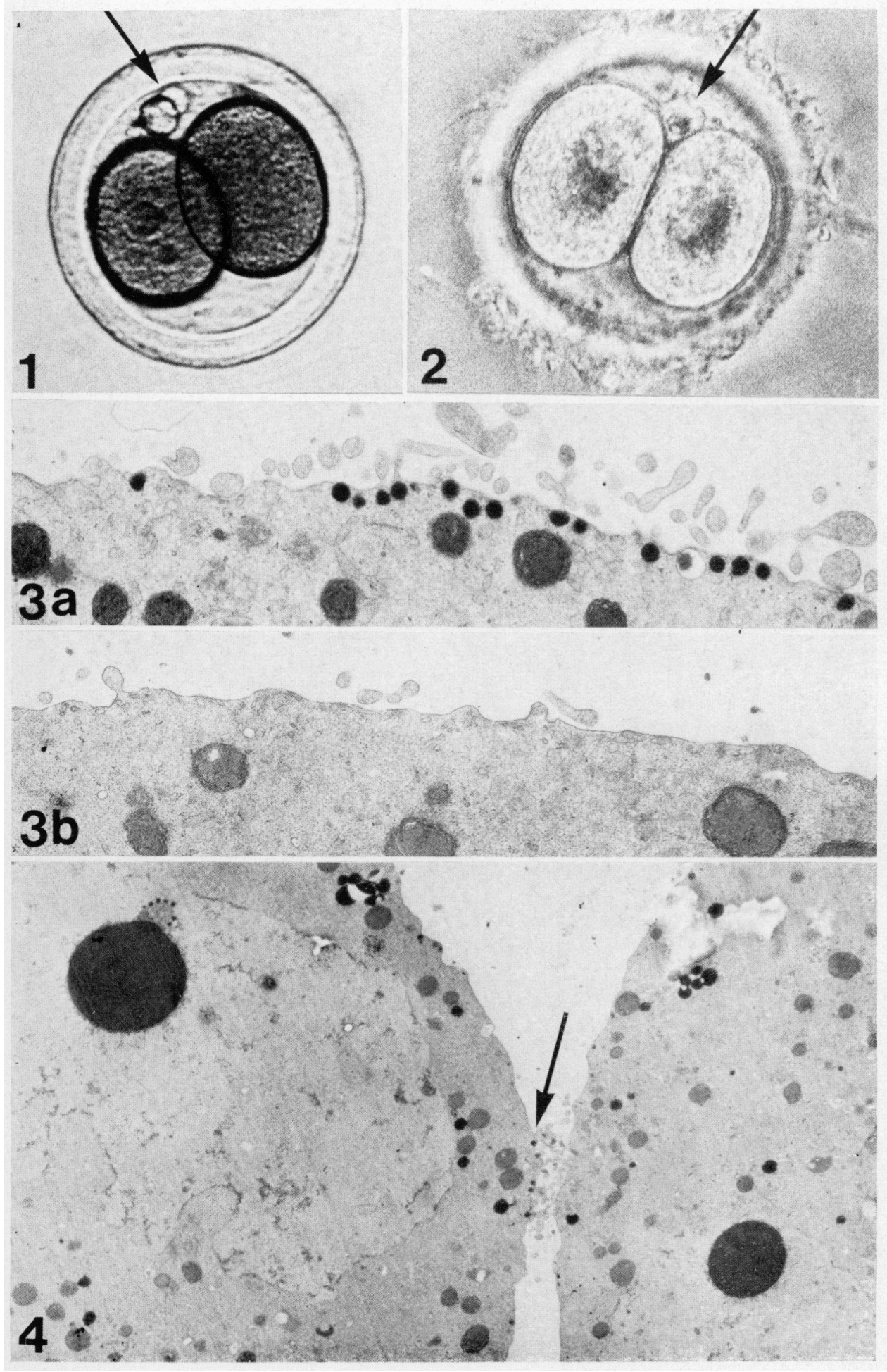

(Facing p. 144) 
Cleavage occurred in ova exposed to spermatozoa pretreated with enzymes or body fluids, except for $\beta$-amylase and BFF (Table 1). Since $\beta$-amylase appears to shorten capacitation in vivo (Johnson \& Hunter, 1972; Kirton \& Hafs, 1965), our results suggest that the effect on the spermatozoa is not sufficient to produce changes in the ova. Spermatozoa placed in preovulatory uterine fluid did not induce cleavage but $60 \%$ of ova cleaved when incubated with spermatozoa treated with uterine fluid from a primed doe. The physiological action of postovulatory uterine fluid on spermatozoa was therefore significantly different from that of preovulatory fluid (Brackett et al., 1972; Oliphant \& Brackett, 1973).

Table 1. Cleavage of rabbit ova incubated with treated spermatozoa in vitro

\begin{tabular}{|c|c|c|c|c|}
\hline \multirow[t]{2}{*}{ Treatment } & \multirow{2}{*}{$\begin{array}{l}\text { Preinsemination } \\
\text { incubation time }\end{array}$} & \multirow{2}{*}{$\begin{array}{l}\text { No. of } \\
\text { experiments }\end{array}$} & \multicolumn{2}{|c|}{$\begin{array}{l}\text { No. of ova cleaved/no. of } \\
\text { ova inseminated }\end{array}$} \\
\hline & & & Control* & Experimental \\
\hline $\begin{array}{l}\text { Trypsin, } 10 \mu \mathrm{g} / \mathrm{ml} \\
\text { Trypsin, } 50 \mu \mathrm{g} / \mathrm{ml} \\
\text { Trypsin, } 200 \mu \mathrm{g} / \mathrm{ml} \\
\text { Chymotrypsin, } 10 \mu \mathrm{g} / \mathrm{ml} \\
\beta \text {-Amylase } \\
\text { McGoy's modified medium } \\
\text { Postovulatory uterine fluid } \\
\text { Human follicular fluid } \\
\text { Human follicular fluid } \\
\text { Bovine follicular fluid }\end{array}$ & $\begin{array}{l}45 \mathrm{~min} \\
45 \mathrm{~min} \\
45 \mathrm{~min} \\
45 \mathrm{~min} \\
1 \mathrm{hr} \\
1 \mathrm{hr} \\
1 \mathrm{hr} \\
1 \mathrm{hr} \\
12 \mathrm{hr} \\
1 \mathrm{hr}\end{array}$ & $\begin{array}{l}4 \\
1 \\
1 \\
2 \\
3 \\
3 \\
5 \\
4 \\
6 \\
3\end{array}$ & $\begin{array}{l}11 / 12(91 \cdot 6) \\
4 / 4(100) \\
4 / 4(100) \\
9 / 10(90) \\
12 / 12(100) \\
14 / 15(93 \cdot 3) \\
25 / 26(96 \cdot 1) \\
13 / 14(92 \cdot 8) \\
16 / 16(100) \\
13 / 14(92 \cdot 8)\end{array}$ & $\begin{array}{r}22 / 34(64 \cdot 7) \\
5 / 5(100) \\
4 / 6(60 \cdot 6) \\
10 / 15(66 \cdot 6) \\
0 / 24(0) \\
9 / 19(47 \cdot 3) \\
24 / 40(60) \\
42 / 66(63 \cdot 6) \\
32 / 51(62 \cdot 7) \\
0 / 27(0)\end{array}$ \\
\hline
\end{tabular}

Figures in parentheses are percentages.

* Spermatozoa capacitated in utero.

$\uparrow$ Treated spermatozoa.

The results obtained with BFF are at variance with those in the mouse (Iwamatsu \& Chang, 1969) and hamster (Barros \& Garavagno, 1970) in which BFF was effective in capacitating spermatozoa. Human FF appears to be effective in rodents (Mukherjee \& Lippes, 1972) as well as in rabbits. Rosado, Velázquez \& Lara-Ricalde (1973) demonstrated that HFF affected the surface coat of human spermatozoa and proposed this as a mechanism for capacitation. Spermatozoa incubated in McCoy's medium induced cleavage as in previous reports (Iwaki, 1971).

When examined by light microscopy, eggs exposed to treated spermatozoa appeared to develop normally. Polar bodies were extruded and the cleaved cells were indistinguishable from control ova (Pl. 1, Figs 1 and 2). On electron microscope examination, these ova were seen to retain large numbers of cortical granules. The granules were not randomly distributed but were present in some segments of the cortical cytoplasm and absent in others (Pl. 1, Figs $3 \mathrm{a}$ and $3 \mathrm{~b}$ ). These data raise an interesting question about the homogeneity of the population of cortical granules since only some disappear. Mitochondria, yolk bodies, the Golgi complex, nuclei and nucleoli (Pl. 1, Fig. 4) could not be distinguished from those of fertilized ova. 
These results suggest that ova were activated rather than fertilized. This would imply that spermatozoa are converted to activating agents by incubation in test media. Modifications in the spermatozoa were not due to incubation for the times designated since spermatozoa incubated in fertilization medium had no effect. The stimulus by treated spermatozoa appears to differ from other activating stimuli, such as cold shock (Longo, 1974), where the population of cortical granules is the same as that in the unfertilized ovum. Alternatively, if these ova are fertilized, the effect of the spermatozoa on the ovum is not identical to those produced by spermatozoa capacitated in vivo. Experiments to establish that these ova are fertilized are in progress.

This work was supported by a Ford Foundation Grant. The authors are indebted to Ms Kathleen Forest and Ms Patricia Eager for invaluable assistance.

\section{REFERENCES}

Austrs, G. R. (1951) Observations on the penetration of the sperm into the mammalian egg. Aust. $\mathcal{F}$. sci. Res. Ser. B, 4, 581-589.

Barros, C. \& Garavagno, A. (1970) Capacitation of hamster spermatozoa with blood sera. F. Reprod. Fert. 22, 381-384.

Brackett, B. G., Mills, J. A., Oliphant, G., Seitz, H. M., Jeitles, G. G. \& Mastroianni, L. (1972) Preliminary efforts to capacitate rabbit sperm in-vitro. Int. F. Fert. 17, 86-92.

Chang, M. G. (1951) Fertilizing capacity of spermatozoa deposited into the Fallopian tubes. Nature, Lond. 168, 697-698.

Dukelow, W. R., Chernofr, H. N. \& Williams, W. L. (1967) Properties of decapacitation factor and presence in various species. F. Reprod. Fert. 14, 393-399.

Fraser, L. R., Dandekar, P. \& Vaidya, R. A. (1971) In vitro fertilization of tubal rabbit ova partially or totally denuded of follicular cells. Biol. Reprod. 4, 229-233.

Gordon, M., Dandekar, P. V. \& Bartoszewicz, W. (1974) Ultrastructural localization of surface receptors for Concanavalin A on rabbit spermatozoa. F. Reprod. Fert. 36, 211-214.

Hayashi, M. J. (1964) Distribution of $\beta$-glucuronidase activity in rat tissues employing the naphthol AS-B1 glucuronide hexazonium pararosanilen method. F. Histochem. Cytochem. 12, 659-669.

Iwaki, A. (1971) Some observations on the fertilization of rabbit tubal ova in vitro. Proc. 7 th Wld Congr. Fert. Steril., Tokyo/Kyoto, Abstr. No. 151, p. 42.

Inamatsu, T. \& Ghang, M. G. (1969) In vitro fertilization of mouse eggs in the presence of bovine follicular fluid. Nature, Lond. 224, 919-920.

Johnson, W. L. \& Hunter, A. G. (1972) Seminal antigens: their alteration in the genital tract of female rabbits and during partial in-vitro capacitation with $\beta$-amylase and $\beta$-glucuronidase. Biol. Reprod. 7, 332-340.

Kapeller, M., Gal-oz, R., Grover, N. B. \& Doljanski, F. (1973) Natural shedding of carbohydrate containing macromolecules from cell surfaces. Expl Cell Res. 79, 152-158.

KIRTON, K. T. \& HAFs, H. D. (1965) Sperm capacitation by uterine fluid or $\beta$-amylase in-vitro. Science, N.Y. 150, 618-619.

Longo, F. J. (1974) Ultrastructural analysis of parthenogenic rabbit eggs. Anat. Rec. 178, 404-405.

MukhERJEe, A. B. \& Lippes, J. (1972) Effect of human follicular and tubal fluids on human, mouse and rat spermatozoa in vitro. Can. F. Genet. Cytol. 14, 167-174.

OLIPHANT, G. \& BRACKeTt, B. G. (1973) Immunological assessment of surface changes of rabbit sperm undergoing capacitation. Biol. Reprod. 9, 404-413.

Rosado, A., Velázquez, A. \& Lara-Rigalde, R. (1973) Cell polarography. II. Effect of neuroaminidase and follicular fluid upon the surface characteristics of human spermatozoa. Fert. Steril. 24, 349-354.

Rosado, A., Hick, J. J., Reyes, A. \& Branco, I. (1974) Capacitation in vitro of rabbit spermatozoa with cyclic adenosine monophosphate and human follicular fluid. Fert. Steril. 25, 821-824. 